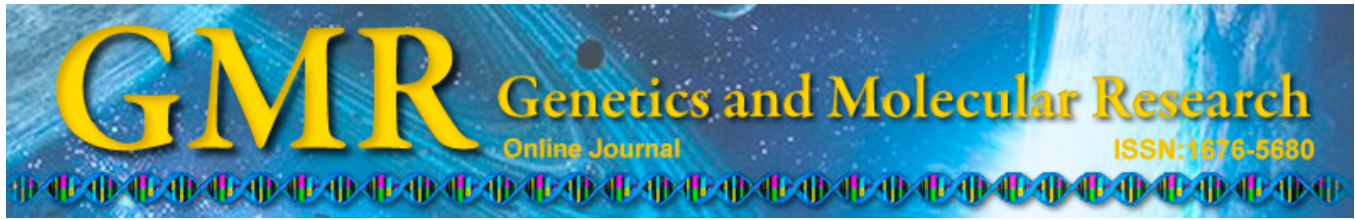

\title{
Polymorphisms of the bovine $M C 3 R$ gene and their associations with body measurement traits and meat quality traits in Qinchuan cattle
}

\author{
W.-C. Yang, Y.-N. Wang, A. Cui and L.-S. Zan \\ College of Animal Science and Technology, Northwest A\&F University, \\ Shaanxi, China \\ Corresponding author: L.-S. Zan \\ E-mail: zanlinsen2003@163.com
}

Genet. Mol. Res. 14 (4): 11876-11883 (2015)

Received September 18, 2014

Accepted April 27, 2015

Published October 5, 2015

DOI http://dx.doi.org/10.4238/2015.October.5.1

ABSTRACT. The melanocortin 3 receptor $(M C 3 R)$ gene, which
belongs to the rhodopsin-like family A of the G protein-coupled receptor
family, plays a crucial role in feed efficiency and energy homeostasis.
The aim of this study was to examine associations between bovine
$M C 3 R$ gene polymorphisms and body measurement traits (BMTs) and
meat quality traits (MQTs). We identified three synonymous mutations
(T429C, T537C, and T663C) in exon 1 of the $M C 3 R$ gene in Chinese
Qinchuan beef cattle (N $=271)$ by sequencing. $D^{\prime}$ and $r^{2}$ values revealed
that these three SNPs were in strong linkage disequilibrium (LD) ( $r^{2}>$
0.33); the T429C and T537C SNPs were in complete LD ( $D^{\prime}=1$ and
$\left.r^{2}=1\right)$. Association analyses revealed that the SNPs were significantly
associated with BMTs and MQTs in Qinchuan cattle. Individuals with the
wild homozygotic genotypes g.TTTT and g.TT had significantly higher
values of chest depth, heart girth, back fat thickness, intramuscular fat
content, and loin muscle area than the mutant heterozygotic genotypes
g.TCTC and g.TC. These results suggest that the $M C 3 R$ gene affects 
MQTs in Qinchuan cattle, and that it may be a good candidate gene for marker-assisted selection.

Key words: $M C 3 R$; Qinchuan cattle; Body measurement trait; Meat quality trait; Single-nucleotide polymorphism

\section{INTRODUCTION}

Qinchuan cattle are the best-known native breed for beef production in China, and are mainly reared in Shaanxi province. Body measurement traits (BMTs) and meat quality traits (MQTs) play an important role in the evaluation of beef cattle productivity, and have received increasing attention in cattle selection and breeding. The identification of quantitative trait loci and major-effect genes that are associated with these traits is a powerful and efficient strategy for the molecular breeding of beef cattle, and has been the main objective of several genetic studies (Pedersen et al., 2009; Ribeca et al., 2014).

The melanocortin 3 receptor ( $M C 3 R$ ) gene, which belongs to the rhodopsin-like family A of the $\mathrm{G}$ protein-coupled receptor family, plays a crucial role in feed efficiency and energy homeostasis (Begriche et al., 2011; Irani et al., 2011), and its polymorphisms have been studied in terms of their effects on growth traits, fat deposition, and obesity (Jiang et al., 2002; Sharma et al., 2008; Tao, 2010; Santos et al., 2011; Müller et al., 2012). Previous studies have shown that $M C 3 R$ knock-out (-/-) mice exhibit reduced lean mass, increased fat mass, and metabolic adaptation to restricted feeding (Chen et al., 2000). In humans, over 20 mutations in $M C 3 R$ have been identified (Cieslak et al., 2013), and 6Thr $>$ Val, 81 Val $>$ Ile, and 335Ile $>$ Ser are strongly predisposing to obesity (Tao, 2007). In the porcine $M C 3 R$, two silent single-nucleotide polymorphisms (SNPs) have been detected, and are significantly related to daily weight gain (Weisz et al., 2011). Furthermore, extensive studies on the $M C 3 R$ gene in the chicken, dog, red fox, and Chinese raccoon dog have revealed variable levels of polymorphism (Sharma et al., 2008; Skorczyk et al., 2011), and association studies conducted on chickens and red foxes have revealed significant relationships with body weight, carcass weight, feed efficiency, and abdominal fat mass. However, few studies have been conducted on $M C 3 R$ and bovine BMTs and MQTs.

Therefore, we investigated the effects of $M C 3 R$ on bovine BMTs and MQTs. Sequencing was used to detect variants of the $M C 3 R$ gene in cattle, and relationships with BMTs and MQTs were evaluated in order to detect potential markers that could be used for selection by breeders.

\section{MATERIAL AND METHODS}

\section{DNA samples and data collection}

In total, 271 blood samples were collected from pure-bred Qinchuan cattle, which were fed corn and corn silage after weaning at 6 months of age. At 24 months of age the following BMTs were measured, as previously described (Ozkaya and Bozkurt, 2009): body length (BL), withers height (WH), hip height (HH), rump length (RL), hip width (HW), chest depth (CD), heart girth (HG), and pin bone width (PBW). The following MQTs were mea- 
sured using an ultrasound scanner (Brethour, 1994; Hamlin et al., 1995), also at 24 months of age: back fat thickness (BFT), intramuscular fat content (IFC), and loin muscle area (LMA). Genomic DNA samples were obtained from the blood samples using standard methods (Sambrook and Russell, 2001).

\section{SNP detection and genotyping}

A pair of primers (1F, 5'-AACAGTCCCAGACAGCCTACA-3' and 5'-CCTTCT TTCACTCCCATTTCC-3') was designed based on the DNA sequence of bovine MC3R (GenBank accession No. ID281798) using the oligonucleotide design tool Primer 5.0 software, in order to amplify a 421-bp product to find SNPs. Mutations were detected using DNA pools as templates from 20 individual genomic samples that were randomly selected from the cattle. SNPs and novel mutations were identified by direct sequencing, using an ABI PRIZM 377 DNA sequencer (Applied Biosystems, Foster City, CA, USA).

\section{Statistical analysis}

Gene frequencies were determined by direct counting, and the Hardy-Weinberg equilibrium was analyzed by a chi-square test using SAS 8.1 (SAS Institute Inc., Cary, NC, USA). Pairwise linkage disequilibrium (LD) was measured using the SHEsis platform (Shi and He, 2005). Association analyses between the SNP-marker genotypes of the $M C 3 R$ gene and the BMTs and MQTs (BL, WH, HH, RL, HW, CD, HG, PBW, BFT, LMA, and IFC) were performed using the SAS 8.1 software. All of the analyses were conducted in two steps: firstly using a full animal model and then using a reduced animal model. The full animal model included marker genotype, season of birth (spring or fall), birth year, sire, farm, and sex as fixed effects, and individual animal as a random effect. Sire, farm, sex, birth year, and season of birth were not significant in the full model; hence, the following reduced model was used for the final analysis:

$$
\mathrm{y}_{\mathrm{ik}}=\mathrm{u}+\mathrm{G}_{\mathrm{i}}+\mathrm{e}_{\mathrm{ik}}
$$

where $y_{i k}$ is the value of the trait, $u$ is the population mean, $G_{i}$ is the fixed effect of genotype, and $e_{i k}$ is the random error.

\section{RESULTS}

\section{Genotypic and allelic frequencies}

We amplified and sequenced pooled DNA data (Pool-Seq) from an exon of the $M C 3 R$ gene in 20 Qinchuan cattle. The sequences obtained were compared with a previously reported sequence (GenBank accession No. 505405), and three synonymous mutations (T429C, T537C, and T663C) in exon 1 of $M C 3 R$ were identified (Figure 1). The genotyping of these SNPs, which was conducted using DNA sequencing, revealed three genotypes at each locus (Figure 1). The chi-square test indicated that the three mutations were in Hardy-Weinberg equilibrium $(\mathrm{P}>0.05)$ (Table 1). 

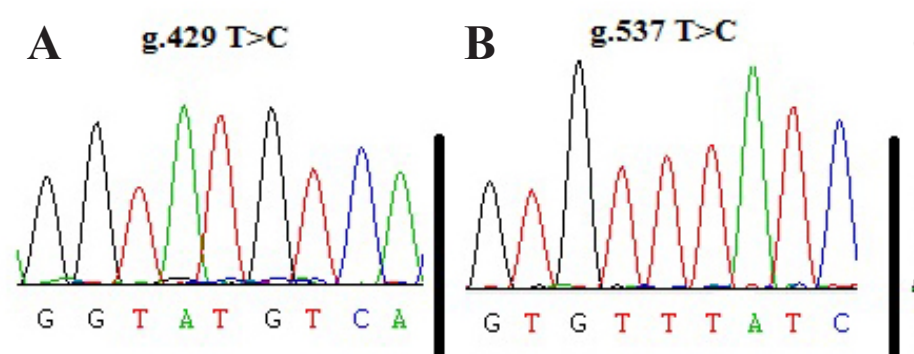

C $\quad$ g.663 T $>$ C
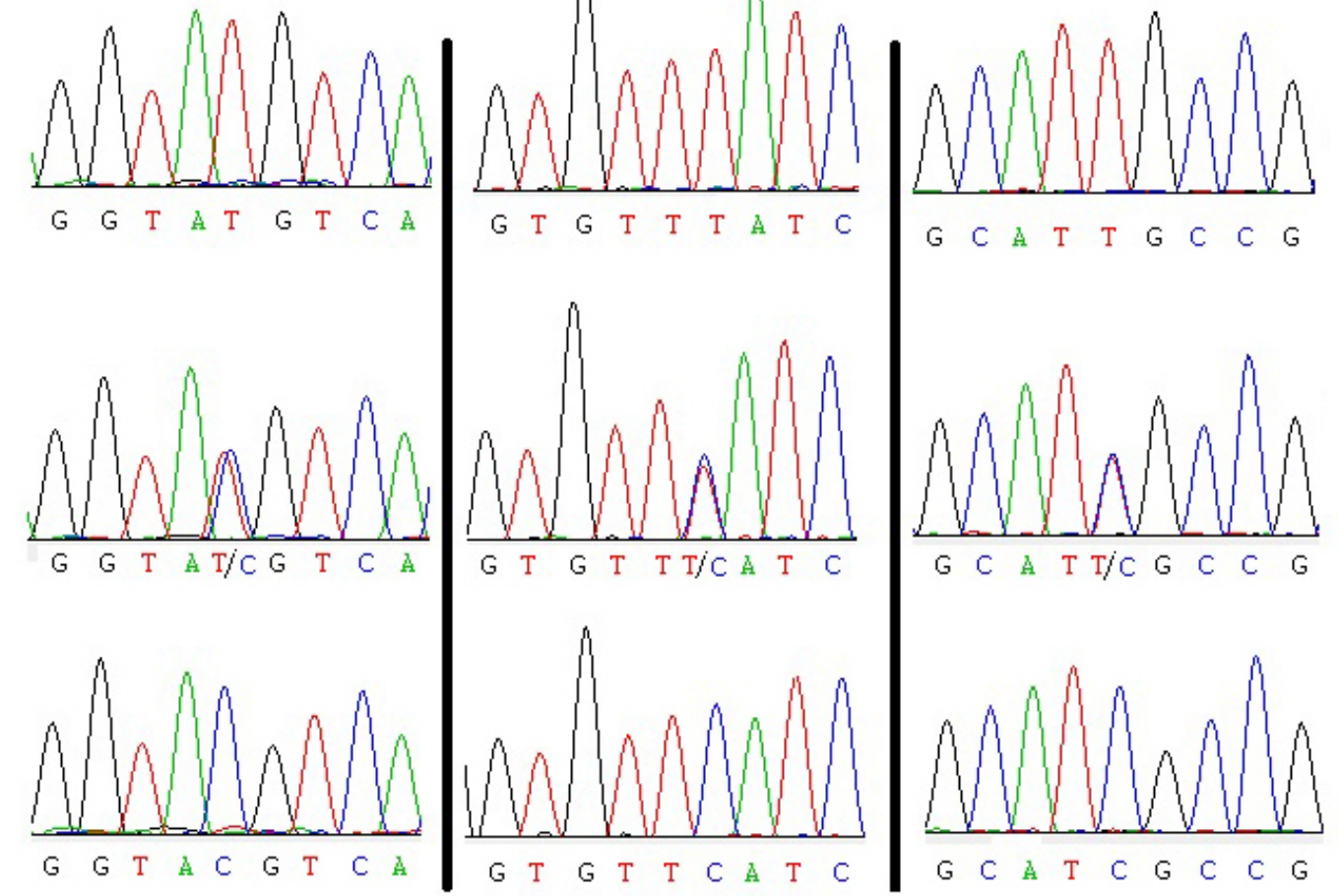

Figure 1. Sequencing maps of three mutations in the bovine $M C 3 R$ gene. A. B. C. Sequencing map of T429C, $\mathrm{T} 537 \mathrm{C}$ and $\mathrm{T} 663 \mathrm{C}$, respectively.

Table 1. Genotypic and allelic frequencies (\%) at the $M C 3 R$ gene for the SNP in Qinchuan cattle populations.

\begin{tabular}{|c|c|c|c|c|}
\hline \multirow[t]{2}{*}{ Loci } & \multirow[t]{2}{*}{ Observed genotypes $(\mathrm{N})$} & \multicolumn{2}{|c|}{ Frequencies } & \multirow[t]{2}{*}{$\chi^{2}$ (P value) } \\
\hline & & Genotypes & Alleles & \\
\hline \multirow[t]{3}{*}{$\mathrm{T} 429 \mathrm{C}$} & TT (216) & 0.797 & Т 0.886 & \multirow[t]{3}{*}{$4.312(\mathrm{P}=0.116)$} \\
\hline & $\mathrm{TC}(48)$ & 0.177 & C 0.114 & \\
\hline & $\mathrm{CC}(7)$ & 0.026 & & \\
\hline \multirow[t]{3}{*}{$\mathrm{T} 537 \mathrm{C}$} & TT (216) & 0.797 & Т 0.886 & \multirow[t]{3}{*}{$4.312(\mathrm{P}=0.116)$} \\
\hline & $\mathrm{TC}(48)$ & 0.177 & C 0.114 & \\
\hline & $\mathrm{CC}(7)$ & 0.026 & & \\
\hline \multirow[t]{3}{*}{$\mathrm{T} 663 \mathrm{C}$} & TT (190) & 0.701 & Т 0.828 & \multirow[t]{3}{*}{$2.756(\mathrm{P}=0.252)$} \\
\hline & $\mathrm{TC}(69)$ & 0.255 & C 0.172 & \\
\hline & CC (12) & 0.044 & & \\
\hline
\end{tabular}

\section{LD and haplotype analyses}

In order to determine the linkage relationships between the three variants, two popular measures of LD, commonly denoted by $r^{2}$ and $D^{\prime}$, were used between pairs of biallelic markers (Ardlie et al., 2002); if $r^{2}>0.33$, the LD was considered to be strong (Ardlie et al., 2002). The 
$D^{\prime}$ and $r^{2}$ values we obtained suggested that the three SNPs were in strong LD (Table 2), and the T429C and T537C SNPs were in complete LD $\left(D^{\prime}=1\right.$ and $\left.r^{2}=1\right)$ (Table 2). We found three genotypes: a wild homozygotic g.TTTT genotype, a heterozygotic g.TCTC genotype, and a mutant homozygotic g.CCCC genotype. Therefore, T429C and T537C were analyzed together and marked as a single locus for the association analysis.

Table 2. Estimated values of linkage disequilibrium for SNPs bovine $M C 3 R$ Qinchuan cattle.
\begin{tabular}{lccc}
\hline SNPs & T429C-T537C & T429C-T663C & T537C-T663C \\
\hline$r^{2}$ & 1.000 & 0.661 & 0.661 \\
$D^{\prime}$ & 1.000 & 1.000 & 1.000 \\
\hline
\end{tabular}

\section{Association between MC3R genotypes and BMTs and MQTs}

Associations between the MC3R genotypes and the BMTs and MQTs were analyzed, and the results are presented in Tables 3 and 4 (genotypes with frequencies lower than 0.05 were ignored). Animals with the g.TTTT genotype had significantly higher values of BL, CD, HG, BFT, LMA, and IFC than those with the g.TCTC genotype $(\mathrm{P}<0.05)$. At the polymorphic locus 663, individuals with the g.TT genotype had significantly higher values of $\mathrm{WH}, \mathrm{CD}, \mathrm{HG}$, BFT, LMA, and IFC than those with the g.TC genotype $(\mathrm{P}<0.05)$.

Table 3. Associations of combined genotypes of the $M C 3 R$ gene with meat quality traits in Qinchuan cattle.

\begin{tabular}{|c|c|c|c|c|}
\hline \multirow[t]{2}{*}{ Loci } & \multirow[t]{2}{*}{ Genotypes } & \multicolumn{3}{|c|}{ Meat quality traits } \\
\hline & & BFT & LMA & IFC \\
\hline \multirow[t]{2}{*}{ T429C-T537C } & g.TTTT (216) & $0.917 \pm 0.030^{\mathrm{a}}$ & $47.496 \pm 1.347^{\mathrm{a}}$ & $7.346 \pm 0.114^{\mathrm{a}}$ \\
\hline & g.ТCTC (48) & $0.824 \pm 0.048^{\mathrm{b}}$ & $38.460 \pm 2.765^{b}$ & $6.912 \pm 0.271^{\mathrm{b}}$ \\
\hline \multirow[t]{2}{*}{ T663C } & g.TT (190) & $0.923 \pm 0.033^{\mathrm{a}}$ & $48.293 \pm 1.440^{\mathrm{a}}$ & $7.405 \pm 0.113^{\mathrm{a}}$ \\
\hline & g.TC (69) & $0.835 \pm 0.038^{\mathrm{b}}$ & $39.500 \pm 2.252^{\mathrm{b}}$ & $6.949 \pm 0.234^{b}$ \\
\hline
\end{tabular}

Values with different superscript letters $(\mathrm{a}, \mathrm{b})$ within the same line differ significantly at $\mathrm{P}<0.05$.

\section{DISCUSSION}

The bovine $M C 3 R$ gene, mapped to chromosome 13 and containing a single 972-bp exon (GenBank accession No. JN210913), is very similar to the human (86.7\%) and mouse (87.6\%) $M C 3 R$ gene. We amplified and sequenced the exon within the bovine $M C 3 R$ gene. A comparison with a previously reported sequence identified three SNPs within the bovine MC3R gene by Pool-Seq (T429C, T537C, and T663C), and a chi-square test revealed that they were in Hardy-Weinberg equilibrium and exhibited strong LD. Interestingly, a previous study also found three SNPs of the $M C 3 R$ gene in Xiangxi cattle, and these were in strong LD (Luoreng et al., 2014). These results indicate that $M C 3 R$ could be used as a molecular marker in marker-assisted selection.

Our statistical analyses revealed that the three synonymous SNPs affected BMTs and MQTs. Individuals with the wild homozygotic genotypes g.TTTT and g.TT had significantly higher values of $\mathrm{CD}, \mathrm{HG}, \mathrm{BFT}$, LMA, and IFC than did the mutant heterozygotic genotypes g.TCTC and g.TC. Although these three mutations do not change amino acid sequences, synonymous SNPs can affect in vivo protein folding, mRNA stability (Duan et al., 2003), and 


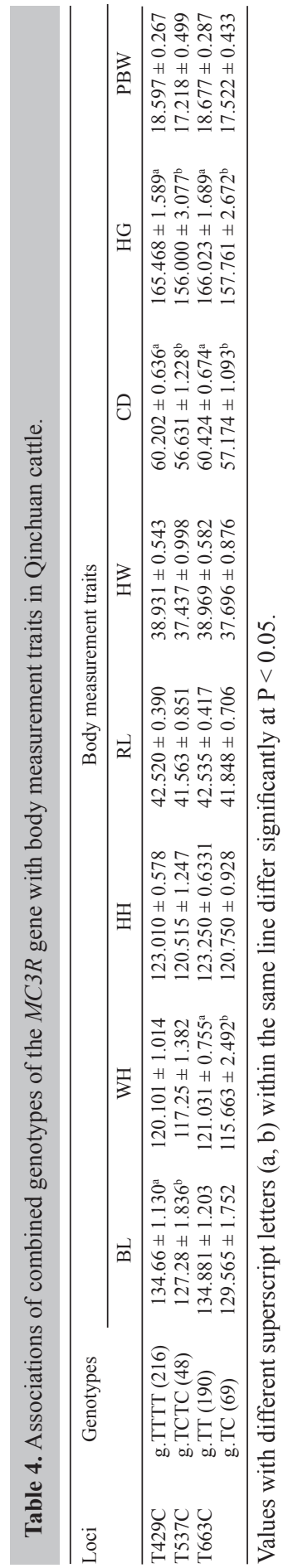


splicing (Pagani et al., 2005), and consequently affect function as well as gene expression and phenotype (Kimchi et al., 2007; Sauna et al., 2007). Synonymous mutations in $M C 3 R$ are closely associated with daily weight gain, body weight, and feed efficiency in pigs and red foxes (Skorczyk et al., 2011; Weisz et al., 2011); further studies are required in order to investigate how SNPs affect variations in these traits. BMTs and MQTs are quantitative traits controlled by multiple genes (Boukha et al., 2011). So, due to the negative effects of other genes, it is not sure that a candidate gene may have effect in another breed (Ma et al., 2011; Liu et al., 2014). Therefore, our results need to be confirmed with much larger sample sizes and in other populations.

In conclusion, we found that T429C, T537C, and T663C polymorphisms in the bovine $M C 3 R$ gene were associated with BMTs and MQTs. These data strongly suggest that $M C 3 R$ polymorphisms may be used as genetic markers for the breeding of beef cattle; however, further studies with larger sample sizes and in other populations are required to confirm these findings.

\section{Conflicts of interest}

The authors declare no conflict of interest.

\section{ACKNOWLEDGMENTS}

Research supported by the National Natural Science Foundation of China (\#31402044), the Postdoctoral Scientific Foundation of China (\#2014M552499), the Start-Up Project of Doctoral Scientific Research (\#Z111021304), and the China National Twelfth "Five Year" Science and Technology Support Project (\#2011BAD28B04-03).

\section{REFERENCES}

Ardlie KG, Kruglyak L and Seilstad M (2002). Patterns of linkage disequilibrium in the human genome. Nat. Rev. Genet. 3: 299-309.

Begriche K, Levasseur PR, Zhang J, Rossi J, et al. (2011). Genetic dissection of the functions of the melanocortin-3 receptor, a seven-transmembrane G-protein-coupled receptor, suggests roles for central and peripheral receptors in energy homeostasis. J. Biol. Chem. 286: 40771-40781.

Boukha A, Bonfatti V, Cecchinato A, Albera A, et al. (2011). Genetic parameters of carcass and meat quality traits of double muscled Piemontese cattle. Meat Sci. 89: 84-90.

Brethour JR (1994). Estimating marbling score in live cattle from ultrasound images using pattern recognition and neural network procedures. J. Anim. Sci. 72: 1425-1432.

Chen AS, Marsh DJ, Trumbauer ME, Frazier EG, et al. (2000). Inactivation of the mouse melanocortin-3 receptor results in increased fat mass and reduced lean body mass. Nat. Genet. 26: 97-102.

Cieslak J, Majewska KA, Tomaszewska A, Skowronska B, et al. (2013). Common polymorphism (81Val>lle) and rare mutations (257Arg $>$ Ser and 335Ile $>$ Ser) of the MC3R gene in obese Polish children and adolescents. Mol. Biol. Rep. 40: 6893-6898.

Duan J, Wainwright MS, Comeron JM, Saitou N, et al. (2003). Synonymous mutations in the human dopamine receptor D2 (DRD2) affect mRNA stability and synthesis of the receptor. Hum. Mol. Genet. 12: 205-216.

Hamlin KE, Green RD and Cundiff LV (1995). Real-time ultrasonic measurement of fat thickness and longissimus muscle area: II. Relationship between real-time ultrasound measures and carcass retail yield. J. Anim. Sci. 73: 1725-1734.

Irani BG, Xiang Z, Yarandi HN, Holder JR, et al. (2011). Implication of the melanocortin-3 receptor in the regulation of food intake. Eur. J. Pharmacol. 66: 80-87.

Jiang SW, Jacobsson L, Kerje S, Andersson L, et al. (2002). Studies of relationship between the melanocortin-3 receptor gene and body weight in chicken for high and low weight lines intercross. Yi Chuan Xue Bao 29: 322-325.

Kimchi SC, Oh JM, Kim IW, Sauna ZE, et al. (2007). A "silent" polymorphism in the MDR1 gene changes substrate specificity. Science 315: 525-528.

Genetics and Molecular Research 14 (4): 11876-11883 (2015)

CFUNPEC-RP www.funpecrp.com.br 
Liu M, Li M, Wang S, Xu Y, et al. (2014). Association analysis of bovine Foxa2 gene single sequence variant and haplotype combinations with growth traits in Chinese cattle. Gene 536: 385-392.

Luoreng ZM, Wang XP, Ma Y, Li F, et al. (2014). Three novel SNPs in the coding region of the bovine MC3R gene and their associations with growth traits. Biochem. Genet. 52: 116-124.

Ma L, Qua YJ, Huaia YT, Lia ZJ, et al. (2011). Polymorphisms identification and associations of KLF7 gene with cattle growth traits. Livest. Sci. 135: 1-7.

Müller A, Möller M, Adams LA, Warren RM, et al. (2012). Comparative analysis of a putative tuberculosis-susceptibility gene, MC3R, and pseudogene sequences in cattle, African buffalo, hyena, rhinoceros and other African bovids and ruminants. Cytogenet. Genome Res. 136: 117-122.

Ozkaya S and Bozkurt Y (2009). The accuracy of prediction of body weight from body measurements in beef cattle. Archiv. Fur. Tierzucht 52: 371-377.

Pagani F, Raponi M and Baralle FE (2005). Synonymous mutations in CFTR exon 12 affect splicing and are not neutral in evolution. Proc. Natl. Acad. Sci. 102: 6368-6372.

Pedersen LD, Sorensen AC and Berg P (2009). Marker-assisted selection can reduce true as well as pedigree-estimated inbreeding. J. Dairy Sci. 92: 2214-2223.

Ribeca C, Bonfatti V, Cecchinato A, Albera A, et al. (2014). Effect of polymorphisms in candidate genes on carcass and meat quality traits in double muscled Piemontese cattle. Meat Sci. 96: 1376-1383.

Sambrook J and Russell DW (2001). Molecular cloning: a laboratory manual. 2nd edn. Cold Spring Harbor Laboratory, New York.

Santos JL, De la Cruz R, Holst C, Grau K, et al. (2011). Allelic variants of melanocortin 3 receptor gene (MC3R) and weight loss in obesity: a randomized trial of hypoenergetic high - versus low - fat diets. PLoS One 6: e19934.

Sauna ZE, Kimchi-Sarfaty C, Ambudkar SV and Gottesman MM (2007). Silent polymorphisms speak: how they affect pharmacogenomics and the treatment of cancer. Cancer Res. 67: 9609-9961.

Sharma P, Bottje W and Okimoto R (2008) Polymorphisms in uncoupling protein, melanocortin 3 receptor, melanocortin 4 receptor, and pro-opiomelanocortin genes and association with production traits in a commercial broiler line. Poult. Sci. 87: 2073-2786.

Shi YY and He L (2005). SHEsis, a powerful software platform for analyses of linkage disequilibrium, haplotype construction, and genetic association at polymorphism loci. Cell Res. 15: 97.

Skorczyk A, Flisikowski K, Szydlowski M, Cieslak J, et al. (2011). Association of MC3R gene polymorphisms with body weight in the red fox and comparative gene organization in four canids. Anim. Genet. 42: 104-107.

Tao YX (2007). Functional characterization of novel melanocortin-3 receptor mutations identified from obese subjects. Biochim. Biophys. Acta 1772: 1167-1174.

Tao YX (2010). Mutations in the melanocortin-3 receptor (MC3R) gene: impact on human obesity or adiposity. Curr. Opin. Investig. Drugs 11: 1092-1096.

Weisz F, Urban T, Chalupová P and Knoll A (2011). Association analysis of seven candidate genes with performance traits in Czech Large White pigs. Czech. J. Anim. Sci. 56: 337-344. 